\title{
The effects of treating persimmon (Diospyros lotus) seeds with moist-chilling and growth regulators on seeds germination, the subsequent seedling characters and their induced drought tolerance.
}

\author{
El-Refaey F. A. El-Dengawy ${ }^{1}$ and Ahmed A. Hussein ${ }^{2}$ \\ ${ }^{1}$ Pomology Department, Faculty of Agriculture, Damietta University 34517, Damietta/Egypt \\ ${ }_{2}^{2}$ Biology Department, Faculty of Science, King Khalid University, Abha, Saudi Arabia.
}

\begin{abstract}
The present experiment aimed at investigating the effects of seed pre-treatment with moist-chilling $(m c h), G A_{3}, B A$ or their combinations on seed germination and subsequent drought resistance of the resulting seedlings. The obtained results indicated that increasing the moist-chilling period from 4 to 8 weeks progressively significantly increased the seeds germination percentages (average from $51.2 \%$ to $97.2 \%$ ) and significantly decreased the time to 50\% germination (T50) (average from 47days to 27.3 days). The control one (non-moistchilled seeds) gave the lowest germination percentage (22.6\%) and required the highest T50 (72.6 days). The 4 weeks-chilled seeds soaked in BA gave the most satisfactory results as it yielded high germination percentage (average 85.2\%), low T50 (average 31.2 days) and saved about at least 4 weeks which would have otherwise being required for moist-chilling of the seeds. The best vegetative characteristics of 2.5-month-old persimmon seedlings were obtained from seeds treated with 8week-moist-chilling solely or with 4week- moist chilling followed by soaking in $20 \mathrm{ppm} \mathrm{BA}$ solution for $16 \mathrm{hr}$. After exposure the subsequent seedlings to 24 days drought period, the results revealed that increasing the moist-chilling period decreased proline content of the seedlings leaves and roots, while increased their leaf resistance to water vapour (LRWV) $(9.9,11.45 \& 19.65 \mathrm{sec} / \mathrm{cm}$ for 0 , 4,8 weeks of $m c h$, respectively). Generally, seeds pretreated with BA solely gave seedlings with significantly higher root proline content than those of the other treatments, and hence showing more drought resistance features. After the 24 days of drought, leaves of the seedlings resulting from either 4 or 8-weeks-chilled seeds had significantly higher values of chlorophyll (chl $a, b)$ and total soluble carbohydrates (TSC) than those of their corresponding ones resulting from non-chilled seeds.

In view of the above findings, the best combination that gave the most satisfactory results was soaking in BA of the seeds which were mois-chilled for 4 weeks.
\end{abstract}

Keywords: persimmon, seed germination, seedling characteristics, drought tolerance, moist- chilling; Gibberellins, Benzylaminopurine.

\section{Introduction}

Persimmon is a deciduous fruit tree adapted to warm temperate and sub-tropical climates Mowat et al. ${ }^{[1]}$. It has a primary centre in the mountains of central China and a secondary centre in Japan Zeven and Zhukovsky ${ }^{[2]}$. Recent expansion of persimmon cultivation is mostly in temperate and sub-tropical regions outside the major production areas. The major producers are China, Japan, Brazil, Korea and Italy. Minor producers include Israel, U. S. A., New Zealand, Australia, Spain, Georgia (C. I. S.), Egypt, India and Chile.

Many fruit producing areas are currently threatened by severe drought. This situation will have potent effects on plants such as persimmon trees affected, and will need to be managed by producers to minimize adverse effects. Water is the most powerful regulator of plant growth and development. To understand the physiological and molecular bases of plant responses to mild to moderate water deficits is therefore of utmost importance to modulate the appropriate balance between vegetative and reproductive development, to improve crop water use Blum ${ }^{[3]}$ and to control fruit quality under deficit irrigation Chaves et al. ${ }^{[4]}$.

With more water shortages and drought periods ahead, planting trees and other plants that are drought resistant can be beneficial. Drought resistance requires tree leaves use water efficiently, and continue to grow and make food at relatively low water concentrations. Drought resistance involves characteristics like extensive root systems, thick leaf waxes and bark, good stomata control, and the capacity for leaf cells to function at low water contents. Water stress markedly reduces the amounts of auxins, gibberellins and cytokinins, while it reversibly raises the amounts of ABA Abdalla and El-Khoshiban ${ }^{[5]}$. Generally, the environmental stresses especially drought stress, give rise to accumulation of soluble carbohydrates, proline and free amino acids as well as antioxidants compounds. These solutes are low molecular weight, highly soluble compounds that are non toxic at high cellular 
concentration and protect cellular components from dehydration injury, thus are referred to as osmoprotectants and compatible solutes Reddy et al. ${ }^{[6]}$ and Shao et al. ${ }^{[7]}$.

Various dormancy breaking and germination stimulating treatments have been tried with seeds of many fruit species such as apricot El-Khoreiby \& Salem ${ }^{[8]}$, papaya Nagao and Furutani ${ }^{[9]}$, persimmon Taha ${ }^{[10]}$, peach El-Dengawy ${ }^{[11]}$ and loquat Polat ${ }^{[12]}$ and El-Dengawy ${ }^{[13]}$. In this respect, gibberellic acid and moist-chilling treatments seem the most promising in many woody species Powell ${ }^{[14]}$.

Persimmon seed coat can affect seed germination through inhibiting and mechanically restricting the embryo growth Taha ${ }^{[10]}$, Hayden ${ }^{[15]}$ and Fadhil et al. ${ }^{[16]}$. Increase cold stratification period up to 10 weeks overcome seed dormancy and promote seed germination of Diospyros lotus Oh et al. ${ }^{[17]}$. It is known that the persimmon seeds are hard to germinate and needs additional treatments to break dormancy and such germinated seeds are generally used as a rootstock for grafting and producing new trees required for new plantations. Persimmon is also hard to propagate by cuttings or tissue culture. Thus producing rootstocks form seeds for grafting is critically required.

Most research approaches of the subject of dormancy have concentrated on finding ways to dormancy breakage. However, the effects of breaking seed dormancy by moist chilling and growth regulators of Persimmon seeds and their effects on the seedling vegetative characteristics under drought stress has been neglected. Therefore, in this experiment we have primarily aimed at (a) finding out a practical method to promote kaki seed germination and the subsequent seedling growth by means of moist-chilling, application of GA3, BA, or the combination of the two hormones, and (b) to investigate the effect of such treatments on drought tolerance of the subsequent seedlings.

\section{Materials And Methods}

The present research was carried out on seeds of "Tarabols" Persimmon (Diospyros lotus) during two successive seasons, 2009 and 2010 . This study was conducted in the greenhouse $\left(28 \pm 2^{\circ} \mathrm{C}\right.$ and $22 \pm 2^{\circ} \mathrm{C}$ at daylight and night, respectively) and laboratories in Faculty of Science, King Khalid University, Abha, Saudi Arabia. The tested seeds were obtained by extraction from mature fruits which were picked from one tree of 14 years old in a private orchard at Tawfikia village, Damietta Governorate. The extracted seeds were immediately washed with tap water, air dried, divided to 12 groups. Each group was divided into 3 replicates (21 seeds for each) and subjected to one of the following treatments: Soaking into tap water only for $16 \mathrm{hr}$ (control, T1); Soaking into a gibberellic acid $\left(\mathrm{GA}_{3}\right)$ solution at $200 \mathrm{ppm}$ for $16 \mathrm{hr}(\mathrm{T} 2)$; Soaking into a Benzylaminopurine (BA) solution at $20 \mathrm{ppm}$ for 16 $\mathrm{hr}$ (T3); Soaking into a mixed solution of $200 \mathrm{ppm} \mathrm{GA}_{3}$ and $20 \mathrm{ppm} \mathrm{BA}$ for16 $\mathrm{hr}$ (T4); Four weeks moist-chilling at $5 \pm 1^{\circ} \mathrm{C}$ (T5); Four weeks moist-chilling at $5 \pm 1^{\circ} \mathrm{C}$ followed by soaking into $200 \mathrm{ppm} \mathrm{GA}_{3}$ solution for $16 \mathrm{hr}$ (T6); Four weeks moist-chilling at $5 \pm 1^{\circ} \mathrm{C}$ followed by soaking into $20 \mathrm{ppm}$ BA solution for $16 \mathrm{hr}$ (T7); Four weeks moist-chilling at $5 \pm 1^{\circ} \mathrm{C}$ followed by soaking into a mixed solution of $200 \mathrm{ppm} \mathrm{GA}_{3}$ and $20 \mathrm{ppm} \mathrm{BA}$ for 16 $\mathrm{hr}$ (T8); Eight weeks moist-chilling at $5 \pm 1^{\circ} \mathrm{C}$ (T9); Eight weeks moist-chilling at $5 \pm 1^{\circ} \mathrm{C}$ followed by soaking into $200 \mathrm{ppm} \mathrm{GA}_{3}$ solution for $16 \mathrm{hr}$ (T10); Eight weeks moist-chilling at $5 \pm 1^{\circ} \mathrm{C}$ followed by soaking into 20 ppm BA solution for $16 \mathrm{hr}$ (T11); Eight weeks moist-chilling at $5 \pm 1^{\circ} \mathrm{C}$ followed by soaking into a mixed solution of $200 \mathrm{ppm} \mathrm{GA} 3$ and $20 \mathrm{ppm} \mathrm{BA}$ for $16 \mathrm{hr}$ (T12).

The treated seeds were sown in first Marsh using nine perforated black polyethylene bags for each treatment (about $4 \mathrm{~kg}$ weight) contained a medium of peat-moss : sand : clay $(1: 2: 1 \mathrm{v} / \mathrm{v})$. After sowing the bags were watered regularly and shaded under greenhouse. At 50 days after sowing the subsequent seedlings irrigated with $250 \mathrm{ml}$ tap water for each bag then subjected to 24 days drought period. The following subjects were studied.

\subsection{Seed germination behaviour}

The germination percentage was calculated starting from 20 days after sowing and so at 10 days-intervals up to 50 days. Time (in days) to obtain $50 \%$ germination referred to as T50 Heydecker and Wainwright ${ }^{[18]}$ was also calculated using the following formula:

$$
\mathrm{T} 50=\left[\left(\mathrm{t}_{2}-\mathrm{t}_{1}\right) \times 50 \%+\left(\mathrm{p}_{2} \mathrm{t}_{1}-\mathrm{p}_{1} \mathrm{t}_{2}\right)\right] /\left(\mathrm{p}_{2}-\mathrm{p}_{1}\right) .
$$

Where, $t_{1}=$ time at which the germination percentage is less than $50 \%, t_{2}=$ time at which the germination percentage is more than $50 \%$, and $\mathrm{p}_{1}$ and $\mathrm{p}_{2}$ are the measurements of germination percentage occurring at $\mathrm{t}_{1}$ and $\mathrm{t}_{2}$, respectively.

\subsection{Seedling characteristics}

Nine seedlings of 2.5-months old randomly collected from each treatment, after 24 days drought period (3seedlings/replicate) were used for seedling characteristics measurements. These measurements included seedling height $(\mathrm{cm})$, leaf area $\left(\mathrm{cm}^{2}\right)$, root length $(\mathrm{cm})$, secondary roots number and dry weight of seedling.

\subsection{Drought resistance measurements on the subsequent seedlings}




\subsubsection{Leaf resistance for water vapor (LRWV) measurement}

After 24 days drought period on the subsequent seedlings, the measurements of LRWV were determined from readings $\left(\mathrm{sec} \mathrm{cm}^{-1}\right)$ of a Delta-T, AP4 porometer, 128 Low Road Burwell, Cambridge CB5 0EJ, UK, on the median portion of the youngest fully expanded leaf avoiding the mid rib.

\subsubsection{Biochemical measurements}

The following biochemical measurements were determined on 2.5-months old seedlings resulted from the tested different germination treatments and subjected to 24 days of drought period.

\subsection{2a. Proline determination}

Proline concentration in leaves of droughted seedlings was determined following the method of Bates et al. ${ }^{[19]}$. Leaf samples were harvested at the end of the experiment. A $0.3 \mathrm{~g}$ of fresh weight was mixed with $9.0 \mathrm{ml}$ aliquot of $3 \%(\mathrm{~W} / \mathrm{V})$ sulfosalicylic acid in glass tubes covered at the top and boiled in a water bath at $100^{\circ} \mathrm{C}$. The mixture was centrifuged at $2000 \mathrm{~g}$ for $5 \mathrm{~min}$ at $25^{\circ} \mathrm{C}$. A $200 \mu \mathrm{l}$ aliquot of the extract was mixed with $800 \mu \mathrm{l}$ distilled water and $14 \mathrm{ml}$ of the reagent mixture $(30 \mathrm{ml}$ glacial acetic acid, $20 \mathrm{ml}$ distilled water and $0.5 \mathrm{~g}$ of ninhydrin), and boiled at $100^{\circ} \mathrm{C}$ for $1 \mathrm{~h}$. After cooling the mixture, we added $6.0 \mathrm{ml}$ of toluene. The chromophore containing toluene was separated and absorption at $520 \mathrm{~nm}$ was read, using toluene as a blank. Proline concentration was calculated using L-proline for the standard curve.

\subsection{2b. Total Soluble carbohydrates (TSC) determination}

The TSC was extracted from leaves of droughted seedlings according to Kerepesi et al. ${ }^{[20]}$. Weight of $0.1 \mathrm{~g}$ of leaf fine dry powder was boiled in $10 \mathrm{ml}$ distilled deionized water under shaking for $45 \mathrm{~min}$ and then filtered through qualitative filter paper. An aliquot of this filtrate was used for TSC determination according to Dubois, et al. ${ }^{[21]}$ using D (+)-glucose as standard.

\subsection{2c. Chlorophylls determination}

Four leaf discs $\left(0.25 \mathrm{~cm}^{2}\right.$ each) were sampled from the leaves of droughted seedlings avoiding major veins. Chlorophyll was eluted from the discs by submerging them in $2 \mathrm{ml}$ of N,N-dimethylformamide in the dark for at least $72 \mathrm{~h}$. The amount of absorbance was read at $647 \mathrm{~nm}$ and $664 \mathrm{~nm}$ with UV-vis spectrophotometer (Model UV1601PC, Shimadzu) and used to calculate leaf a and b chlorophyll concentrations according to equations of Moran ${ }^{[22]}$.

\subsection{Statistical analysis}

The obtained data were statistically analyzed as a factorial experimental design $\left(\mathrm{SAS},{ }^{[23]}\right)$ applying the least significant difference (LSD) at $5 \%$ for the comparison among the treatment means. Duncan's new multiple range tests and regression analysis was also used.

\section{Results}

\subsection{Seed germination behaviour}

For both seasons, the non-moist-chilled seeds treated with BA gave significantly higher germination percentages (table 1) and significantly lower number of days to $50 \%$ germination (T50) compared with $\mathrm{GA}_{3}$ and the control (no growth regulators) treatments. Thus, the germination percentages values for these three treatments were $34.5,20.3$ and $22.6 \%$ respectively, while their recorded averages of T50 value were $65.3,73$ and 72.5 days respectively.

Increasing the moist-chilling period significantly increased the germination percentages while significantly decreased the T50. In recognition to this, the germination \% values were $22.6,51.2$ and $97.2 \%$ and the T50 averages were $72.5,47$ and 27.3 days for 0,4 and 8 weeks moist-chilling periods respectively.

Application of BA after 4 weeks moist-chilling period gave significantly higher germination percentage and significantly lower T50 compared with solely 4 weeks moist-chilling and other applications of $\mathrm{GA}_{3} \mathrm{or} \mathrm{GA}_{3}$ and BA combination after the same moist-chilling period.

The highest germination percentages as well as the lowest number of days to $50 \%$ germination (T50) were on both seasons associated with the solely 8 week moist-chilling treatment (T9). Additional treatment of the 4 weeks-chilled kaki seeds with BA gave the most satisfactory results. Thus, it yielded high germination percentage, gave comparable T50 data as that of T9 and saved about at least 4 weeks which would have otherwise being required for moist-chilling of the seeds.

\subsection{Seedling characteristics}


The data of the response of vegetative characteristics namely, seedling height $(\mathrm{cm})$, leaf area $\left(\mathrm{cm}^{2}\right)$, root length $(\mathrm{cm})$, number of secondary roots and dry weight $(\mathrm{g})$, in 2.5-month-old kaki seedlings are shown in Table 2. The values for all these parameters were significantly higher under all treatments compared with their control ones.

The leaf area $\left(\mathrm{cm}^{2}\right)$, root length $(\mathrm{cm})$, number of secondary roots and the dry weight of the seedlings resulting from seeds pretreated with BA (T3) alone were significantly higher than their corresponding ones resulting from seeds treated with $\mathrm{GA}_{3}$ (T2) solely. All measured vegetative characteristics of the resulting seedlings were significantly increased by augmentation of the moist-chilling period.

The effects of the interaction between growth regulators (GR) and the moist-chilling treatments of the seeds on the vegetative characters of the resulting seedlings differed depending on the type of GR used and the moist-chilling duration. Whearas, the 4week-moist-chilling then BA treated seeds produced seedlings had significantly higher vegetative characters than their corresponding ones receiving the same treatment, but after 8 week-moist-chilling period. However, these findings were contrary to those found under $\mathrm{GA}_{3}$ treatment.

The best vegetative characteristics obtained were those of the 8week-moist-chill solely (T9) followed by application of BA for the seeds pretreated with 4week- moist chilling (T7).

\subsection{Drought resistance measurements on the subsequent seedlings}

\subsubsection{Proline content and Leaf resistance for water vapor (LRWV)}

The proline content of the leaves and roots decreased but the leaf diffusive resistance to water vapour increased with increasing the moist-chilling period, especially after 24 days drought period (Table 3 ). The resulting seedlings from seeds pretreated with $\mathrm{GA}_{3}$ alone yielded significantly lower leaf and root proline contents compared with the control (no moist-chilling, no growth regulator).

Generally, seeds pretreated with BA solely gave seedlings with significantly higher root proline content than those of the other treatments, and hence showing more drought resistance features. The seedlings emerging from non-moist-chilled seeds treated with $\mathrm{GA}_{3}$ and $\mathrm{BA}$ in combination (T4), showed more drought tolerance

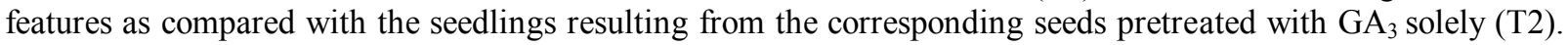
Thus, the seedling leaf proline content of the former decreased while that of the root increased compared with those of the latter $\left(\mathrm{GA}_{3}\right.$ solely).

The same previously mentioned findings regarding the no moist-chilling seeds treated with combination of $\mathrm{GA}_{3}$ and $\mathrm{BA}$ was recorded for the combination of these two GRs when the 4 and 8week moist chilling conditions were considered.

\subsubsection{Contents of pigments and total soluble carbohydrates}

After exposure to 24 days of drought, the leaves of the seedlings resulting from either 4 or 8 -weekschilled seeds had significantly higher chlorophyll a and total soluble carbohydrates contents than those of the corresponding ones resulting from non-chilled seeds (Table 4). Shifting the seed chilling period from 4 to 8 weeks resulted in increasing the total soluble carbohydrate content of the seedlings exposed to 24 days of drought.

Treatment of the non-chilled seeds with either $\mathrm{GA}_{3}$, BA or their combination, resulted in non significant increase of the total soluble carbohydrates content of the 24-day droughted seedlings.

Application of BA to the 4week-chilled seeds, resulted in increasing the leaf total soluble carbohydrates content of the resulting seedlings compared with 4 week moist-chilling alone or in combination with GA $\mathrm{A}_{3}$. The combinations of $\mathrm{GA}_{3}$ and 4 week-chilling periods, showed no significant differences in the soluble carbohydrates contents of the leaves of the resulting seedlings compared with those of the same chilling period. Treatment of the seeds with the combination of $\mathrm{GA}_{3}$ and $\mathrm{BA}$ improved the contents of the chlorophylls and the total soluble carbohydrates of the resulting seedling leaves after 24 days of drought.

There was a significantly positive correlation (values between $0.62 * *$ and $0.70 * *$ ) between the chlorophylls a \& b and the total soluble carbohydrates contents of the leaves of the resulting seedlings subjected to 24 days of drought. Similarly, there was a positive correlation between chlorophylls a and $b$ (values between $0.59 * *$ and $0.81 * *)$.

\section{Discussion}

\section{Seed germination behaviour}

In the present study, exogenously applied GA3 alone could not alleviate germination of persimmon seed. This result coincided with those of Sauls and Campbell ${ }^{[24]}$ with 'Waldin' avocado seeds and El-Dengawy ${ }^{[13]}$ with loquat seeds where they found no effect for soaking in $250 \mathrm{ppm} \mathrm{GA}_{3}$ solution on seed germination. The lack of $\mathrm{GA}_{3}$ effectiveness in stimulating seed germination might be referred to the following possibilities: a negative effect of $\mathrm{GA}_{3}$ on the level of some enzymes activity (glutamate-oxaloacetate transaminase, pyruvate kinase and 
malate dehydrogenase) and consumption of nucleotides in the synthesis of nucleic acid El-Dengawy ${ }^{[11]}$ and/or the production of a proteinaceous germination inhibitor. Gibberellins are reported to have differential response in the germination of tree seeds. The inhibitory effect of abscisic acid (ABA) on germination of the conifer seeds was overcome very successfully by $\mathrm{GA}_{3}$ alone in comparison with cytokinin (BA) and it's combination with $\mathrm{GA}_{3}$ $\mathrm{Kabar}^{[25]}$. In general, $\mathrm{GA}_{3}$ is effective in breaking the non-deep physiological dormancy, but it does not overcome the deep physiological dormancy Baskin and Baskin ${ }^{[26]}$.

Although the highest germination percentages as well as the lowest number of days to $50 \%$ germination (T50) were on both seasons associated with the solely 8 week moist-chilling treatment (T9), but it may be said that T7 (the 4 weeks -chilled seeds soaked in BA) gave the most satisfactory results as it yielded high germination percentage, gave comparable T50 data as that of T9 and saved about at least 4 weeks which would have otherwise being required for moist-chilling of the seeds. Such results might be attributed to the synergistic effect of cold stratification and BA in breaking seed dormancy and stimulating germination. Therefore we suggest that there are different interactions among $\mathrm{BA}, \mathrm{GA}_{3}$ and cold stratification in affecting kaki seeds dormancy and germination. These findings are in line with those of $\mathrm{Oh}$ et al. ${ }^{[17]}$ on Diospyros lotus seeds, they reported that the number of days required for $50 \%$ germination was less with higher germination temperature, longer stratification (up to 10 weeks), and alternating temperature. Samaan et al. ${ }^{[2]}$ with apricot seeds also indicated that the most effective treatment in augmentation of seed germination and germination velocity was moist-chilling at $5 \pm 1 \mathrm{oC}$ for 15 days followed by soaking into kinetin solution of $10 \mathrm{ppm}$ for $24 \mathrm{hr}$. They added that embryos of seeds treated by such combination contained the higher values of total soluble phosphorus, soluble organic phosphorus and total reducing sugars as well as a higher number of free amino acids. Therefore, the combination of cytokinin and cold stratification increases growth potential of embryo so that the radical can break through the seed coat resulting in germination. Moreover, the stimulating effect of moist-chilling and cytokinin combination on germination ability of dormant seeds can be attributed to the antagonistic effect of cytokinin on action of inhibitors present in dormant seeds Khan ${ }^{[28]}$. Similarly, El-Dengawy ${ }^{[13]}$ showed that loquat seeds dormancy may be broken by moist-chilling treatment for 3 weeks at $5 \pm 1{ }^{\circ} \mathrm{C}$ or 1 week of moist-chilling followed by soaking in $250 \mathrm{ppm}$ $\mathrm{GA}_{3}$ solution for $20 \mathrm{~h}$. to significantly increase germination percentage. Recently, results of Fadhil, et al. ${ }^{[16]}$ indicated that water soaking of "Lotus" kaki seeds for $72 \mathrm{hr}$. gave the highest germination percentage, whereas, the lowest was from the seeds soaked for $48 \mathrm{hr}$. in $300 \mathrm{mg} \cdot \mathrm{l}^{-1} \mathrm{GA}_{3}$. Rawat et al ${ }^{[29]}$ using the seeds of Abies pindrow and Picea smithiana and their overall results showed that soaking seeds in $\mathrm{GA}_{3}\left(10 \mathrm{mg} \cdot \mathrm{L}^{-1}\right)$ for $24 \mathrm{~h}$, moist chilling for 15 days, and germinating at $10^{\circ} \mathrm{C}$ produced an effective germination in both the species.

\section{Seedling characteristics}

The best vegetative characteristics of 2.5-month-old kaki seedling namely, seedling height, leaf area, root length, number of secondary roots and dry weight, were obtained from seeds pretreated with 8 week- moistchilling solely or 4week- moist chilling followed by application of BA. The trend of kaki seedlings in this experiment was consistent with previous reports regarding the effect on seedling characters of using seed pretreatment with hormones. Ganesh et al. ${ }^{[30]}$ found that seedling establishment of two Green gram pulse varieties resulting from seeds presoaked in various solutions of Indole acetic acid (IAA), Gibberellic acid (GA3) and Indole Butyric Acid (IBA), showed significant increases at 5ppm concentrations in the seedling growth of these two pulse varieties, contrary pre-soaking the seeds in distilled water responded. Kochanovoundá et al ${ }^{[31]}$ studied the effect of BA, and indole-3-butyric acid (IBA) on adventitious shoot regeneration from dormant persimmon buds and reported that adventitious shoots can be successfully produced in vitro. In another study on persimmon shoot regeneration following hormonal treatments, Tetsumura and Yukinaga ${ }^{[32]}$ obtained a high percentage shoot regeneration confirming the differential reactions of different persimmon cultivars to cultivation media and plant hormones. Furthermore, according to the findings of Amooaghaie ${ }^{[33]}$ with the forage Ferula ovina, moistchilling treatments induced a great alteration in the level of seed soluble protein and hence seed germination and seedling vigour. This is strengthened by the findings Lin et al. ${ }^{[34]}$ on pear seeds and Mullen, et al. ${ }^{[35]}$ on Loblolly pine seed stratification, germination and post-germinative growth.

\section{Drought resistance measurements on the subsequent seedlings}

\section{Proline content and Leaf resistance for water vapor (LRWV)}

Generally, seeds pretreated with BA solely gave seedlings with significantly higher root proline content under drought than those of the other treatments, and hence showing more drought resistance features. Similar results were obtained when the GA3 and BA combination was applied to non-moist chilled seeds or to those moist chilled for 4 or 8 weeks, hence reflecting the profound effects of the hormonal combination as regard to proline accumulation. Such increased levels of proline under drought as seen in the present study, agree with those of other workers. Thus, Verbruggen and Hermans ${ }^{[36]}$ stated that proline is considered to act as an osmolyte protecting cells from damage caused by stress conditions. The capacity to accumulate proline has long been 
correlated with stress tolerance in some plant species Barnett and Nayor ${ }^{[37]}$ and Szabados and Savoure ${ }^{[38]}$. Further, in an attempt to study the effect of seed pretreatment with exogenous application of proline, some authors, Ashraf and Foolad ${ }^{[39]}$ and Wahid et al..$^{[40]}$ found that pre-soaking sugar cane cuttings in proline and glycinebetane proved of considerable help in alleviating the adversities of heat and its accompanying drought stress. These data suggested that both these osmolytes, due to their specific membrane protective properties, can be used to improve stress tolerance in many various plant species including the Diospyros.

The plant hormones cytokinins comprise a class of growth regulators involved in the stress response and antagonize many physiological processes induced by water stress, mainly those mediated by abscisic acid (ABA). Well known is the reversal of ABA-induced stomatal closure by cytokinins Incoll et al. ${ }^{[41]}$, Rulcova and Pospisilova ${ }^{[42]}$ and Werner and Schmulling ${ }^{[43]}$.

\section{Contents of pigments and total soluble carbohydrates}

After exposure to 24 days of drought, it was evident that the effects of GA3, BA or their combination on seedling chlorophylls and TSC parameters were more pronounced on seedlings resulting from moist- chilled seeds compared with those of the corresponding ones resulting from non-chilled seeds. Drought inhibits the photosynthesis of plants and causes changes of chlorophyll contents, damage the photosynthetic apparatus and decreases the activities of Calvin cycle enzymes Monakhova and Chernyadev ${ }^{[44]}$. It also gives rise to accumulation of various low molecular weight substances namely, soluble carbohydrates, proline and free amino acids as well as antioxidants compounds. These osmoprotectants and compatible solutes play important roles in protecting cellular components from dehydration injury Reddy et al. ${ }^{[6]}$ and Shao et al. ${ }^{[7]}$.

Since we imposed severe drought in this research, the decrease in TSC concentration and the chlorophylls contents in the present study may be explained by the adverse effect of drought in damaging the photosynthetic apparatus, and decreasing the activities of Calvin cycle enzymes Monakhova and Chernyadev ${ }^{[44]}$ and hence the drop in TSC production. So, treatment of the seeds with the combination of $\mathrm{GA}_{3}$ and BA resulted a further improved the contents of the chlorophylls and the total soluble carbohydrates of the resulting seedling leaves after 24 days of drought. This is substantiated by the significantly positive correlation (values between $0.62^{* *}$ and $0.70^{* *}$ ) between the chlorophylls ( $\mathrm{a} \& \mathrm{~b}$ ) and the total soluble carbohydrates contents of the leaves of the resulting seedlings subjected to 24 days of drought. Similarly, there was a positive correlation between chlorophylls a and $\mathrm{b}$ (values between $0.59^{* *}$ and $0.81^{* *}$ ).

\section{Conclusion}

As with some other species, Diospyros responds well to seed-moist chilling or BA and GA3 hormonal treatments. This was evident from the response of germination, T50\%, and the acquired drought tolerance of the resulting seedlings. It was also known that any improvement in drought resistance would make a plant more adapted to saline soil. False efficacy is likely to be gained by reliance solely on germination testing; therefore, testing should be extended to the level of physiological aspects of seedling drought tolerance mechanisms. Further work is needed to study the feasibility of using persimmon pretreated seedlings as compatible combination in the process of grafting scions onto seedling rootstocks. Partitioning of TSC and its translocation between the scion and rootstock needs to be investigated together with the rate of healing at the graft union area. Perhaps the choice of Diospyros lotus as rootstock would enhance the translocation of photosynthates and thereby improve the productivity and longevity of persimmon trees.

\section{References}

[1]. Mowat, A.D., Collins, R..J., George, A.P., 1995. cultivation of persimmon (Diospyros kaki L.) under tropical conditions. Acta Hort. (ISHS) 409, 141-150.

[2]. Zeven, A. C., Zhukovsky, P. M., 1975. Dictionary of cultivated plants and their centres of diversity, Wageningen, The Netherlands.

[3]. Blum, A., 2009. Effective use of water (EUW) and not water-use efficiency (WUE) is the target of crop yield improvement under drought stress. Field Crop Research, 112, 119-123.

[4]. Chaves, M.M., Santos, T.P., Souza, C.R, 2007. Deficit irrigation in grapevine improves water-use efficiency while controlling vigour and production quality. Annals of Appl. Biol, 150: 237-252.

[5]. Abdalla, M.M., El-Khoshiban, N.H., 2007. The influence of water stress on growth, relative water content, photosynthetic pigments, some metabolic and hormonal contents of two Triticum aestivum cultivars. J. Appl. Sci. Res. 12, 2062-2074.

[6]. Reddy, A.R., Ramachandra, R.K., Chaitanya, V., Vivekanandan, M., 2004. Drought-induced responses of photosynthesis and antioxidant metabolism in higher plants. J. Plant Physiol. 161, 1189-1202.

[7]. Shao., H.B, Liang, Z.S., Shao, M.A., 2005. Change of antioxidative enzymes and MDA among 10 wheat genotypes at maturation stage under soil water deficits. Colloid. Surf. B: Biointerf. 45, 7-13.

[8]. El-Khoreiby, A.M.K., Salem, T.A., 1985. Effect of stratification and $\mathrm{GA}_{3}$ on seed germination and subsequent seedling growth of apricot and peach. Bull. Fac. Agric. Cairo Univ., Egypt, 36, 299-309. 
[9]. Nagao, M.A., Furutani, S.C., 1986. Improving germination of papaya seed by density separation, potassium nitrate and gibberellic acid. HortScience, 21, 1439-1440.

[10]. Taha, F.A., 1987. Effect of plant growth regulators on seed germination and seedling characters of persimmon root-stock (Diospyrus kaki, L.). Egypt. J. Hort., 14, 15-20.

[11]. El-Dengawy, E.F.A., 1997. Physiological and biochemical studies on seeds dormancy and germination process in deciduous fruit trees. Ph.D. Thesis, Fac. Agric. Mansoura Univ., Egypt.

[12]. Polat, A.A., 1997. Determination of germination rate coefficients of loquat seeds and their embryos stratified in various media for different durations. Turkish J. Agric. Forestry, 21, 219-224.

[13]. El-Dengawy, E.F.A., 2005. Promotion of seed germination and subsequent seedling growth of loquat (Eriobotrya japonica, Lindl) by moist-chilling and $\mathrm{GA}_{3}$ application. Scientia Hort., 105, 331-342.

[14]. Powel, L., 1987. The hormonal control of bud and seed dormancy in woody plants. In: Davies, P.J. (Ed.), Plant Hormones and Their role in Plant Growth and Development. Martinus Nijhof Publishers, Dordrecht, pp.539-552.

[15]. Hayden, R.A. 2001. Persimmons. Purdxe University Cooperative Extension Service, West Lafayette. IN. Ho. 108 W. Koyunco.

[16]. Fadhil, N.N., Alalaf, A.H., Shayal Alalam, A.T., 2013. Effectiveness of gibberellic acid treatment and soaking period on seed germination and seedlings growth of "Lotus" Persimmon rootstock. Mesopotamia J. of Agric. 41, $1-9$.

[17]. Oh, J.H., Kim, S.K., Ahn, H.K., 1988. Studies on seed germination of Diospyros species. J. of the Korean society for horticultural science, 29, 297-303.

[18]. Heydecker, W., Wainwright, H., 1976. More rapid uniform germination of Cyclamen persicum L. Scientia Hort., 5, 183-189.

[19]. Bates, L.S., Waldren, R.P., Teare, I.D., 1973. Rapid determination of free proline for water-stress studies. Plant Soil, 39, 205-207.

[20]. Kerepesi, I., Toth, M., Boross, L., 1996. Water-Soluble Carbohydrates in Dried Plant. J. Agric. Food Chem. 44, 3235-3239.

[21]. Dubois, M., Gilles, K.A. Hamilton, J.K., Rebers, P.A., Smith, F., 1956. Colorimetric method for determination of sugars and related substances. Anal. Chem. 28, 350-356.

[22]. Moran, R., 1982. Formulae for determination of chlorophyllous pigments extracted with N,NDimethylformamide. Plant Physiol. 69, 1376-1381.

[23]. SAS, 1996. User's Guide: Statistics, Version 5 Ed. SAS Institute, Inc. Cary, NC, USA.

[24]. Sauls, J.W., Campbell, C.W., 1980. Avocado seed germination studies. Proc. Flo. State Hort. Soc. 93, 153-154.

[25]. Kabar, K., 1998. Comparative effects of kinetin, benzyladenine, and gibberellic acid on abscisic acid inhibited seed germination and seedling growth of red pine and arbor vitae. Tr. J. of Botany, 22, 1-6.

[26]. Baskin, J.M., Baskin, C.C., 1990. Germination ecophysiology of seeds of the winter annual Chaerophyllum tainturieri: a new type of morphophysiological dormancy. J. Ecol. 78, 993-1004.

[27]. Samaan, L. G., El-Baz, E. E. T., Iraqi M. A., El-Dengawy, E. F. A., 2000. Kinetin as a chemical stimulant to germination ability and subsequent seedlings growth of apricot seeds (Prunus armeniaca L.). Egypt. J. Hort. 27, 157-170.

[28]. Khan, A.A., 1971. Cytokinins: Permissive role in seed germination. Science, 171, 853.

[29]. Rawat., B.S., Khanduri, V.P., Sharma, C.M., 2008. Beneficial effects of cold-moist stratification on seed germination behaviors of Abies pindrow and Picea smithiana. J. Forestry Research, 19, 125-130.

[30]. Ganesh K.S., Sundaramoorthy, P., Baskaran, L., Rajesh., M., Rajasekaran, S., 2013. Effect of Pre-sowing Hardening Treatments Using Various Plant Growth Hormones on Two Varieties of Green Gram Germination and Seedling Establishment. International Journal of Modern Biology and Medicine, 3, 78-87

[31]. Kochanová Z., Naci Onus, Ján Brindza, 2012. Adventitious shoot regeneration from dormant buds of persimmon (Diospyros kaki Thunb.) cv. Hachiya . J Agrobiol 28, 113-118.

[32]. Tetsumura, T., Yukinaga, H., 2002. Comparative rooting of shoot tips of four Japanese persimmon cultivars vs. shoots regenerated from roots cultured in vitro. Hort. Sci. 35, 940-944.

[33]. Amooaghaie, R., 2009. The Effect Mechanism of Moist-Chilling and GA3 on Seed Germination and Subsequent Seedling Growth of Ferula ovina Boiss. Open Plant Sci J., 3, 22-28.

[34]. Lin, C.H., Lee, L.Y, Tseng, M.J., 1991. Effects of stratification and thidiazuron treatment on germination and protein synthesis of Pyrus serotina Rehd. cv. Niauli. Plant Physiol, 96(Suppl): 404.

[35]. Mullen R.T., King J.E., Gifford, D.J., 1996. Changes in embryo mRNA populations occur during loblolly pine seed stratification, germination and postgerminative growth. Physiol. Plant., 97, 545-553.

[36]. Verbruggen, N., Hermans, C., 2008, Proline accumulation in plants: A review, Amino Acids J., 35, 753-759.

[37]. Barnett, N.M., Naylor, A.W., 1966. Amino acid and protein metabolism in Bermuda grass during water stress. Plant Physiol., 41, 1222-1230.

[38]. Szabados, L., Savoure, A., 2010. Proline: a multifunctional amino acid. Trends in Plant Science 15, 89-97.

[39]. Ashraf, M., Foolad, M.R., 2007. Roles of glycine betaine and proline in improving plant abiotic stress resistance. Environ. Exp. Bot., 59, 206-216.

[40]. Wahid, A, Gelani, S., Ashraf, M., Foolad, M.R., 2007. Heat tolerance in plants: an overview. Environ. Exp. Bot., 61, 199-223. 
The effects of treating persimmon (Diospyros lotus) seeds with moist-chilling and growth ....

[41]. Incoll, L.D., Ray, J.P., Jewer, P.C. 1990. Do cytokinins act as root to shoot signals? - In: Davies, W.J., Jeffcoat, B. (ed.): Importance of Root to Shoot Communication in the Responses to Environmental Stress. Pp. 185-197. British Society for Plant Growth Regulation, Bristol.

[42]. Rulcová J.and Pospisilova J.2001: Effect of benzylaminopurine on rehydration of bean plants after water stress. Biologia plantarum 44 (1): 75-81.

[43]. Werner, T., Shmulling, T., 2009. Cytokinin action in plant development. Curr. Opin. Plant Biol. 12, 527-38.

[44]. Monakhova, O.F., Chernyadev, I.I., 2002. Protective role of kartolin-4 in wheat plants exposed to soil drought. Appl. Biochem. Microbiol. 38, 373-380.

Table (1): Effect of $\mathrm{GA}_{3}$, $\mathrm{BA}$ and three moist-chilling periods either alone or in combination on persimmon seeds germination.

\begin{tabular}{|c|c|c|c|c|c|c|c|c|c|c|c|c|}
\hline \multicolumn{3}{|c|}{ Treatments } & \multicolumn{8}{|c|}{ Seed germination $\%$, days from sowing } & \multirow{2}{*}{\multicolumn{2}{|c|}{$\underline{\mathrm{T} 50}$}} \\
\hline \multirow{2}{*}{\multicolumn{2}{|c|}{$\begin{array}{l}\text { MCh } \\
\text { (weeks) }\end{array}$}} & \multirow{2}{*}{$\begin{array}{l}\text { Growth } \\
\text { Regulators }\end{array}$} & \multicolumn{2}{|c|}{20 days } & \multicolumn{2}{|l|}{30 days } & \multicolumn{2}{|c|}{40 days } & \multicolumn{2}{|l|}{50 days } & & \\
\hline & & & $\mathrm{S} 1$ & $\mathrm{~S} 2$ & $\mathrm{~S} 1$ & $\mathrm{~S} 2$ & S1 & S2 & $\mathrm{S} 1$ & $\mathrm{~S} 2$ & $\mathrm{~S} 1$ & S2 \\
\hline$\overline{(\mathrm{T} 1)}$ & 0 & 0 (Control) & $00.0 \mathrm{e}$ & $00.0 \mathrm{~d}$ & $00.0 \mathrm{~g}$ & $00.0 \mathrm{f}$ & $17.5 \mathrm{f}$ & $15.9 \mathrm{f}$ & $23.8 \mathrm{~h}$ & $21.4 \mathrm{f}$ & $73.6 \mathrm{a}$ & $71.5 \mathrm{a}$ \\
\hline (T2) & 0 & 200 ppm $\mathrm{GA}_{3}$ & $00.0 \mathrm{e}$ & $00.0 \mathrm{~d}$ & $03.0 \mathrm{~g}$ & $04.8 \mathrm{f}$ & $14.3 \mathrm{f}$ & 16.7ef & $19.1 \mathrm{~h}$ & $21.4 \mathrm{f}$ & $74.3 \mathrm{a}$ & $71.6 \mathrm{a}$ \\
\hline (T3) & 0 & 20 ppm BA & $00.0 \mathrm{e}$ & $00.0 \mathrm{~d}$ & $11.3 \mathrm{def}$ & 09.5def & $19.0 \mathrm{f}$ & $23.8 \mathrm{e}$ & $33.3 \mathrm{fg}$ & $35.7 \mathrm{e}$ & $66.4 b$ & $64.2 b$ \\
\hline (T4) & 0 & $\mathrm{GA}_{3}+\mathrm{BA}$ & $00.0 \mathrm{e}$ & $00.0 \mathrm{~d}$ & $14.3 \mathrm{de}$ & $19.1 \mathrm{~cd}$ & $28.6 \mathrm{e}$ & $33.3 d$ & $38.1 \mathrm{f}$ & $40.5 \mathrm{e}$ & $61.7 b$ & $55.1 \mathrm{c}$ \\
\hline (T5) & 4 & 0 & $09.5 \mathrm{c}$ & $12.7 \mathrm{~b}$ & $34.9 \mathrm{c}$ & $33.3 b$ & $44.4 \mathrm{~d}$ & $47.6 \mathrm{c}$ & $49.2 \mathrm{e}$ & $53.2 \mathrm{~d}$ & $49.1 \mathrm{c}$ & $44.9 \mathrm{~d}$ \\
\hline (T6) & 4 & 200 ppm $\mathrm{GA}_{3}$ & $00.0 \mathrm{e}$ & $00.0 \mathrm{~d}$ & $09.5 \mathrm{ef}$ & $17.9 \mathrm{cde}$ & $40.5 d$ & $45.2 \mathrm{c}$ & $69.1 d$ & $70.2 \mathrm{c}$ & $43.0 \mathrm{c}$ & $41.2 \mathrm{~d}$ \\
\hline (T7) & 4 & 20 ppm BA & $05.6 \mathrm{~cd}$ & $11.1 \mathrm{bc}$ & $48.1 \mathrm{~b}$ & $53.7 \mathrm{a}$ & $77.8 \mathrm{c}$ & $81.5 b$ & $87.0 \mathrm{~b}$ & $83.3 \mathrm{~b}$ & $32.2 \mathrm{de}$ & $30.1 \mathrm{e}$ \\
\hline (T8) & 4 & $\mathrm{GA}_{3}+\mathrm{BA}$ & $00.0 \mathrm{e}$ & $04.8 \mathrm{~cd}$ & $19.8 d$ & $24.6 b c$ & $44.4 d$ & $49.2 \mathrm{c}$ & $69.1 d$ & $70.2 \mathrm{c}$ & $41.1 \mathrm{~d}$ & $40.2 \mathrm{~d}$ \\
\hline (T9) & 8 & 0 & $14.3 b$ & $14.3 b$ & $57.1 \mathrm{a}$ & $65.9 \mathrm{a}$ & $95.2 \mathrm{a}$ & $90.5 a$ & $100.0 \mathrm{a}$ & $94.4 \mathrm{a}$ & $27.6 \mathrm{e}$ & $27.0 \mathrm{e}$ \\
\hline (T10) & 8 & 200 ppm $\mathrm{GA}_{3}$ & $28.6 a$ & $23.8 \mathrm{a}$ & $64.9 \mathrm{a}$ & $66.7 \mathrm{a}$ & $85.7 b$ & $80.1 b$ & $85.7 b c$ & $81.0 \mathrm{~b}$ & $26.9 \mathrm{e}$ & $26.1 \mathrm{e}$ \\
\hline (T11) & 8 & 20 ppm BA & $04.8 \mathrm{de}$ & $09.5 b c$ & $47.6 \mathrm{~b}$ & $57.1 \mathrm{a}$ & $76.2 \mathrm{c}$ & $81.0 \mathrm{~b}$ & $90.5 \mathrm{ab}$ & $85.7 \mathrm{ab}$ & $30.1 \mathrm{e}$ & $29.0 \mathrm{e}$ \\
\hline (T12) & 8 & $\mathrm{GA}_{3}+\mathrm{BA}$ & $14.3 b$ & $09.5 \mathrm{bc}$ & $47.6 \mathrm{~b}$ & $52.4 \mathrm{a}$ & $71.4 \mathrm{c}$ & $75.0 \mathrm{~b}$ & $76.2 \mathrm{~cd}$ & $81.0 \mathrm{~b}$ & $30.6 \mathrm{e}$ & $30.2 \mathrm{e}$ \\
\hline$F$-test & & & $* * *$ & $* * *$ & $* * *$ & $* * *$ & $* * *$ & $* * *$ & $* * *$ & $* * *$ & $* * *$ & $* * *$ \\
\hline LSD: & $\mathrm{M}$ & & 2.23 & 3.02 & 4.19 & 6.58 & 3.25 & 3.49 & 4.82 & 4.57 & 4.58 & 3.49 \\
\hline & GR & & 2.57 & 3.48 & 4.83 & 7.59 & 3.76 & 4.03 & 5.57 & 5.27 & 5.28 & 4.03 \\
\hline & $\mathrm{MC}$ & $\mathrm{Ch} * \mathrm{GR}$ & 4.23 & 6.16 & 8.28 & 13.54 & 6.66 & 7.30 & 9.72 & 8.76 & 9.28 & 6.79 \\
\hline
\end{tabular}

Values within each column followed by the same letter are not statistically different at 5\% level. ***, Significant at level $p=0.001$. MCh, moist-chilling, T50, time (in days) to obtain $50 \%$ germination. T, treatments. S1, season 2009. S2, season 2010.

Table (2): Response of vegetative characteristics in 2.5-month-old persimmon seedlings (resulted from different germination treatments) subjected to 24 days of drought period.

\begin{tabular}{|c|c|c|c|c|c|c|c|c|c|c|c|c|}
\hline \multicolumn{3}{|c|}{ Treatments } & \multicolumn{10}{|c|}{ Seedling characteristics } \\
\hline \multirow{2}{*}{$\begin{array}{l}\text { MCh } \\
\text { (week) }\end{array}$} & & \multirow{2}{*}{$\begin{array}{l}\text { Growth } \\
\text { regulators }\end{array}$} & \multicolumn{2}{|c|}{$\begin{array}{l}\text { Seedling height } \\
(\mathrm{cm})\end{array}$} & \multicolumn{2}{|c|}{$\begin{array}{l}\text { Leaf area } \\
\left(\mathrm{cm}^{2}\right)\end{array}$} & \multicolumn{2}{|c|}{$\begin{array}{l}\text { Root length } \\
\text { (cm) }\end{array}$} & \multicolumn{2}{|c|}{$\begin{array}{l}\text { Secondary } \\
\text { roots No. }\end{array}$} & \multicolumn{2}{|c|}{$\begin{array}{l}\text { Dry weight } \\
(\mathrm{g})\end{array}$} \\
\hline & & & $\mathrm{S} 1$ & $\mathrm{~S} 2$ & $\mathrm{~S} 1$ & S2 & S1 & S2 & $\mathrm{S} 1$ & $\mathrm{~S} 2$ & S1 & S2 \\
\hline (T1) & 0 & $0 \quad($ Control $)$ & $14.8 \mathrm{i}$ & $13.9 \mathrm{~g}$ & $141 \mathrm{de}$ & $136 f$ & $11.0 \mathrm{~g}$ & $10.6 \mathrm{e}$ & $15.3 \mathrm{~g}$ & $13.5 \mathrm{~d}$ & $1.09 \mathrm{~g}$ & $1.10 \mathrm{f}$ \\
\hline (T2) & 0 & $200 \mathrm{ppm} \mathrm{GA}_{3}$ & $17.3 \mathrm{gh}$ & $17.8 \mathrm{f}$ & $123 \mathrm{f}$ & $121 \mathrm{~g}$ & $13.8 \mathrm{ef}$ & $13.1 \mathrm{~cd}$ & $17.2 \mathrm{ef}$ & $16.4 \mathrm{c}$ & $1.20 \mathrm{f}$ & $1.10 \mathrm{f}$ \\
\hline (T3) & 0 & 20 ppm BA & $17.6 \mathrm{fgh}$ & $18.5 \mathrm{f}$ & $188 \mathrm{~cd}$ & $191 b c$ & $15.3 \mathrm{bc}$ & $16.0 \mathrm{a}$ & $17.7 \mathrm{e}$ & $19.3 b$ & $1.38 \mathrm{~d}$ & $1.47 \mathrm{~d}$ \\
\hline (T4) & 0 & $\mathrm{GA}_{3}+\mathrm{BA}$ & $17.2 \mathrm{~h}$ & $18.2 \mathrm{f}$ & $187 \mathrm{~cd}$ & $179 d$ & $13.0 \mathrm{f}$ & $12.0 \mathrm{~d}$ & $15.7 \mathrm{fg}$ & $15.0 \mathrm{c}$ & $1.48 \mathrm{~cd}$ & $1.42 \mathrm{~d}$ \\
\hline (T5) & 4 & 0 & $18.2 \mathrm{ef}$ & $18.8 \mathrm{ef}$ & $169 d$ & $159 \mathrm{e}$ & $13.7 \mathrm{ef}$ & $15.3 \mathrm{ab}$ & $20.7 \mathrm{c}$ & $18.7 \mathrm{~b}$ & $1.41 \mathrm{~d}$ & $1.23 \mathrm{e}$ \\
\hline (T6) & 4 & $200 \mathrm{ppm} \mathrm{GA}_{3}$ & $18.0 \mathrm{fg}$ & $19.5 \mathrm{bde}$ & $172 \mathrm{~d}$ & $180 \mathrm{~cd}$ & 14.0def & $13.0 \mathrm{~cd}$ & $18.7 \mathrm{de}$ & $15.0 \mathrm{c}$ & $1.31 \mathrm{e}$ & $1.53 \mathrm{~d}$ \\
\hline (T7) & 4 & 20 ppm BA & $19.5 \mathrm{~cd}$ & $20.8 b c$ & $214 \mathrm{ab}$ & $212 \mathrm{a}$ & 16.3ab & $14.7 \mathrm{ab}$ & $27.3 \mathrm{a}$ & $20.7 b$ & $1.88 \mathrm{a}$ & $1.82 \mathrm{~b}$ \\
\hline (T8) & 4 & $\mathrm{GA}_{3}+\mathrm{BA}$ & $19.7 b c$ & $20.2 \mathrm{~cd}$ & $221 \mathrm{a}$ & $217 \mathrm{a}$ & $13.3 \mathrm{f}$ & $15.6 \mathrm{a}$ & $26.7 \mathrm{ab}$ & $24.3 \mathrm{a}$ & $1.59 \mathrm{~b}$ & $1.49 \mathrm{~d}$ \\
\hline (T9 & 8 & 0 & $22.3 a$ & $22.8 \mathrm{a}$ & $193 c$ & $192 b c$ & $17.0 \mathrm{a}$ & $15.8 \mathrm{a}$ & $25.3 b$ & $24.0 \mathrm{a}$ & $1.86 \mathrm{a}$ & $2.01 \mathrm{a}$ \\
\hline (T10) & 8 & $200 \mathrm{ppm} \mathrm{GA} 3$ & $18.8 \mathrm{de}$ & $20.0 \mathrm{~cd}$ & $198 b c$ & $200 b$ & $15.7 b c$ & $12.3 \mathrm{~d}$ & $20.0 \mathrm{~cd}$ & $20.7 b$ & $1.40 \mathrm{~d}$ & $1.80 \mathrm{~b}$ \\
\hline (T11) & 8 & $20 \mathrm{ppm} \mathrm{BA}$ & $19.0 \mathrm{~cd}$ & $20.0 \mathrm{~cd}$ & $172 \mathrm{~d}$ & $164 \mathrm{e}$ & $14.7 \mathrm{cde}$ & $14.0 \mathrm{bc}$ & $17.3 \mathrm{ef}$ & $18.7 \mathrm{~b}$ & $1.55 \mathrm{bc}$ & $1.68 \mathrm{c}$ \\
\hline (T12) & 8 & $\mathrm{GA}_{3}+\mathrm{BA}$ & $20.35 b$ & $21.5 b$ & $193 c$ & $195 b$ & $15.0 \mathrm{~cd}$ & $15.7 \mathrm{a}$ & $20.0 c$ & $15.7 \mathrm{c}$ & $1.41 \mathrm{~d}$ & $1.67 \mathrm{c}$ \\
\hline$F$-test & & & $* * *$ & $* * *$ & $* * *$ & $* * *$ & $* * *$ & $* * *$ & $* * *$ & $* * *$ & $* * *$ & $* * *$ \\
\hline LSD: & MC & & 0.38 & 0.48 & 8.7 & 5.3 & 0.52 & 0.68 & 0.83 & 0.93 & 0.05 & 0.08 \\
\hline & GR & & 0.43 & 0.55 & 10.1 & 6.1 & 0.60 & 0.79 & 0.95 & 1.07 & 0.05 & 0.07 \\
\hline & MC & $\mathrm{Ch}^{*} \mathrm{GR}$ & 0.76 & 0.99 & 18.0 & 10.8 & 0.99 & 1.43 & 1.60 & 1.86 & 0.09 & 0.12 \\
\hline
\end{tabular}

Values within each column followed by the same letter are not statistically different at $5 \%$ level. ***, Significant at level $p=0.001$. MCh, moist-chilling. T, treatments. S1, season 2009. S2, Season 2010. 
The effects of treating persimmon (Diospyros lotus) seeds with moist-chilling and growth ....

Table (3): Response of proline content and leaf resistance to transpiration in persimmon seedling (resulted from different germination treatments) after 12 and 24 days drought period.

\begin{tabular}{|c|c|c|c|c|c|c|c|c|c|c|}
\hline \multicolumn{3}{|c|}{ Treatments } & \multicolumn{4}{|c|}{ Proline (mg/g dry weight) } & \multicolumn{4}{|c|}{ Leaf resistance for water vapor $\left(\mathrm{sec} \mathrm{cm}^{-1}\right)$} \\
\hline \multirow{2}{*}{\multicolumn{2}{|c|}{$\begin{array}{l}\mathrm{MCh} \\
\text { (weeks) }\end{array}$}} & \multirow{2}{*}{$\begin{array}{l}\text { Growth } \\
\text { Regulators }\end{array}$} & \multicolumn{2}{|c|}{ Leaf proline } & \multicolumn{2}{|c|}{ Root-Stem proline } & \multicolumn{4}{|c|}{ after 12 days drought after 24 days drought } \\
\hline & & & $\mathrm{S} 1$ & $\mathrm{~S} 2$ & $\overline{\mathrm{S} 1}$ & $\mathrm{~S} 2$ & $\overline{\mathrm{S} 1}$ & $\mathrm{~S} 2$ & S1 & S2 \\
\hline$\overline{(\mathrm{T} 1)}$ & 0 & 0 (control) & $1.58 \mathrm{a}$ & $1.52 \mathrm{a}$ & $4.61 \mathrm{c}$ & $4.60 \mathrm{c}$ & $3.55 \mathrm{~g}$ & $3.29 \mathrm{~h}$ & $10.93 \mathrm{~g}$ & $8.86 \mathrm{i}$ \\
\hline$(\mathrm{T} 2)$ & 0 & $200 \mathrm{ppm} \mathrm{GA}_{3}$ & $1.31 \mathrm{c}$ & $1.25 \mathrm{c}$ & $2.62 \mathrm{f}$ & $2.49 \mathrm{~g}$ & $5.42 \mathrm{e}$ & $5.49 \mathrm{~cd}$ & $9.28 \mathrm{~h}$ & $8.63 \mathrm{i}$ \\
\hline (T3) & 0 & 20 ppm BA & $1.45 b$ & $1.41 b$ & $6.90 \mathrm{a}$ & $6.78 \mathrm{a}$ & $6.42 \mathrm{c}$ & $6.99 b$ & $13.55 \mathrm{~d}$ & $11.20 \mathrm{de}$ \\
\hline (T4) & 0 & $\mathrm{GA}_{3}+\mathrm{BA}$ & $1.15 \mathrm{e}$ & $1.10 \mathrm{~d}$ & $3.06 \mathrm{e}$ & $2.80 \mathrm{f}$ & $6.01 \mathrm{~d}$ & $5.58 \mathrm{c}$ & $11.3 \mathrm{fg}$ & $10.09 \mathrm{~g}$ \\
\hline (T5) & 4 & 0 & $1.42 \mathrm{bc}$ & $1.39 b$ & $2.06 \mathrm{~g}$ & $2.04 \mathrm{~h}$ & $7.50 \mathrm{a}$ & $6.55 a$ & $12.1 \mathrm{ef}$ & $10.80 \mathrm{ef}$ \\
\hline (T6) & 4 & 200 ppm $\mathrm{GA}_{3}$ & $0.79 \mathrm{ef}$ & $0.77 f$ & $3.20 \mathrm{e}$ & $3.12 \mathrm{e}$ & $3.85 \mathrm{f}$ & $3.67 \mathrm{~g}$ & $10.81 \mathrm{~g}$ & $9.38 \mathrm{~h}$ \\
\hline (T7) & 4 & 20 ppm BA & $0.83 \mathrm{ef}$ & $0.80 \mathrm{f}$ & $1.94 \mathrm{~g}$ & $1.87 \mathrm{~h}$ & $6.58 b c$ & $5.60 \mathrm{c}$ & $13.64 \mathrm{~d}$ & $11.45 \mathrm{~d}$ \\
\hline (T8) & 4 & $\mathrm{GA}_{3}+\mathrm{BA}$ & $0.71 \mathrm{f}$ & $0.70 \mathrm{~g}$ & $1.29 \mathrm{~h}$ & $1.30 \mathrm{i}$ & $6.73 b$ & $6.10 \mathrm{~b}$ & $14.60 \mathrm{c}$ & $12.54 \mathrm{c}$ \\
\hline (T9) & 8 & 0 & $0.93 \mathrm{e}$ & $0.90 \mathrm{e}$ & $1.01 \mathrm{~h}$ & $0.97 \mathrm{j}$ & $5.43 \mathrm{e}$ & $5.07 \mathrm{f}$ & $20.45 a$ & $18.84 \mathrm{a}$ \\
\hline (T10) & 8 & 200 ppm $\mathrm{GA}_{3}$ & $0.71 \mathrm{f}$ & $0.70 \mathrm{~g}$ & $3.98 \mathrm{~d}$ & $3.89 \mathrm{~d}$ & $6.11 \mathrm{~d}$ & $5.4 \mathrm{cde}$ & $12.18 \mathrm{e}$ & $10.39 \mathrm{fg}$ \\
\hline (T11) & 8 & 20 ppm BA & $0.92 \mathrm{e}$ & $0.90 \mathrm{e}$ & $4.69 b c$ & $4.56 \mathrm{c}$ & $5.40 \mathrm{e}$ & $5.20 \mathrm{ef}$ & $11.6 \mathrm{ef}$ & $10.53 \mathrm{fg}$ \\
\hline (T12) & 8 & $\mathrm{GA}_{3}+\mathrm{BA}$ & $0.81 \mathrm{ef}$ & $0.79 \mathrm{f}$ & $5.09 \mathrm{~b}$ & $5.05 \mathrm{~b}$ & $5.94 d$ & $5.3 \mathrm{def}$ & $15.6 \mathrm{bc}$ & $13.46 \mathrm{~b}$ \\
\hline$F$-test & & & $* * *$ & $* * *$ & $* * *$ & $* * *$ & $* * *$ & $* * *$ & $* * *$ & $* * *$ \\
\hline LSD: & & $\mathrm{MCH}$ & 0.07 & 0.03 & 0.19 & 0.09 & 0.08 & 0.07 & 0.42 & 0.28 \\
\hline & & GR & 0.08 & 0.03 & 0.21 & 0.11 & 0.09 & 0.08 & 0.49 & 0.33 \\
\hline & & $\mathrm{MCH}^{*} \mathrm{GR}$ & 0.12 & 0.05 & 0.38 & 0.15 & 0.16 & 0.13 & 0.69 & 0.49 \\
\hline
\end{tabular}

Values within each column followed by the same letter are not statistically different at 5\% level. ***,

Significant at level $p=0.001$. MCh, moist-chilling. T, treatments. S1, season 2009. S2, Season 2010.

Table (4): Response of pigments and total soluble carbohydrates contents in leaves of persimmon seedlings (resulted from different germination treatments) after 24 days drought period.

\begin{tabular}{|c|c|c|c|c|c|c|c|c|}
\hline \multicolumn{3}{|c|}{ Treatments } & \multicolumn{4}{|c|}{ Pigments content ( $\mu \mathrm{g} / \mathrm{cm}^{2}$ of leaf) } & \multirow{2}{*}{\multicolumn{2}{|c|}{$\begin{array}{l}\text { Total soluble carbohydrates } \\
\text { (mg/g dry weight of leaf) }\end{array}$}} \\
\hline & \multirow{2}{*}{$\begin{array}{l}\text { MCh } \\
\text { (weeks) }\end{array}$} & \multirow{2}{*}{$\begin{array}{l}\text { Growth } \\
\text { Regulators }\end{array}$} & \multicolumn{2}{|c|}{ Chlorophyll (a) } & \multicolumn{2}{|c|}{ Chlorophyll (b) } & & \\
\hline & & & S1 & $\mathrm{S} 2$ & S1 & S2 & $\mathrm{S} 1$ & $\mathrm{~S} 2$ \\
\hline$\overline{(\mathrm{T} 1)}$ & 0 & 0 (Control) & $6.5 f$ & $7.7 \mathrm{e}$ & $3.5 \mathrm{e}$ & $5.0 \mathrm{ef}$ & $65.5 \mathrm{ef}$ & $67.2 \mathrm{ef}$ \\
\hline$(\mathrm{T} 2$ & 0 & $200 \mathrm{ppm} \mathrm{GA}_{3}$ & $7.9 \mathrm{e}$ & $8.5 \mathrm{de}$ & $5.4 \mathrm{c}$ & $5.2 \mathrm{de}$ & $67.2 \mathrm{def}$ & $64.4 \mathrm{ef}$ \\
\hline (T3) & 0 & 20 ppm BA & $7.4 \mathrm{e}$ & $9.3 \mathrm{~d}$ & $3.9 \mathrm{e}$ & $4.1 \mathrm{~g}$ & $67.3 \mathrm{def}$ & $65.6 \mathrm{ef}$ \\
\hline (T4) & 0 & $\mathrm{GA}_{3}+\mathrm{BA}$ & $8.8 \mathrm{~d}$ & $10.5 \mathrm{c}$ & $5.0 \mathrm{~cd}$ & $5.5 \mathrm{~cd}$ & $69.4 \mathrm{de}$ & $67.4 \mathrm{e}$ \\
\hline (T5) & 4 & 0 & $11.3 b$ & $12.1 \mathrm{ab}$ & $6.4 \mathrm{ab}$ & $6.1 \mathrm{ab}$ & $80.1 \mathrm{c}$ & $76.1 d$ \\
\hline (T6) & 4 & 200 ppm $\mathrm{GA}_{3}$ & $9.1 d$ & $10.6 \mathrm{c}$ & $4.9 \mathrm{~cd}$ & $5.0 \mathrm{ef}$ & $84.5 \mathrm{c}$ & $81.5 \mathrm{c}$ \\
\hline (T7) & 4 & 20 ppm BA & $12.0 \mathrm{ab}$ & $11.4 \mathrm{bc}$ & $6.9 a$ & $6.2 \mathrm{ab}$ & $97.2 \mathrm{~b}$ & $95.1 \mathrm{~b}$ \\
\hline (T8) & 4 & $\mathrm{GA}_{3}+\mathrm{BA}$ & $12.6 \mathrm{a}$ & $12.5 \mathrm{ab}$ & $6.3 b$ & $5.8 \mathrm{bc}$ & $114.9 \mathrm{a}$ & $112.5 \mathrm{a}$ \\
\hline (T9) & 8 & 0 & $12.3 \mathrm{a}$ & $13.1 \mathrm{a}$ & $6.5 \mathrm{ab}$ & $6.4 \mathrm{a}$ & $100.5 b$ & $97.1 \mathrm{~b}$ \\
\hline (T10) & 8 & 200 ppm $\mathrm{GA}_{3}$ & $12.8 \mathrm{a}$ & $12.5 \mathrm{ab}$ & $6.3 b$ & $5.8 b c$ & $82.4 b$ & $81.7 \mathrm{c}$ \\
\hline (T11) & 8 & 20 ppm BA & $12.4 \mathrm{a}$ & $11.7 \mathrm{bc}$ & $5.3 \mathrm{c}$ & $4.7 f$ & $71.4 d$ & $69.5 \mathrm{e}$ \\
\hline (T12) & 8 & $\mathrm{GA}_{3}+\mathrm{BA}$ & $10.1 \mathrm{c}$ & $10.7 \mathrm{c}$ & $4.7 \mathrm{~d}$ & $5.2 \mathrm{de}$ & $64.5 \mathrm{f}$ & $66.5 \mathrm{ef}$ \\
\hline$F$-test & & & $* * *$ & $* * *$ & $* * *$ & $* * *$ & $* * *$ & $* * *$ \\
\hline \multirow[t]{3}{*}{ LSD: } & \multicolumn{2}{|l|}{$\mathrm{MCh}$} & 0.41 & 0.58 & 0.34 & 0.27 & 2.10 & 1.96 \\
\hline & \multicolumn{2}{|l|}{ GR } & 0.48 & 0.67 & 0.39 & 0.31 & 2.42 & 2.26 \\
\hline & \multicolumn{2}{|c|}{$\mathrm{MCh} * \mathrm{GR}$} & 0.77 & 1.19 & 0.65 & 0.55 & 4.01 & 4.09 \\
\hline
\end{tabular}

Values within each column followed by the same letter are not statistically different at $5 \%$ level. ***,

Significant at level $p=0.001$. MCh, moist-chilling. T, treatments. S1, season 2009. S2, Season 2010. 